\title{
Futsal Sports Coaching Achievements of Banggai Regency (A Case Study in Banggai Regency)
}

\author{
Muhammad Salahuddin, Armin Haluti*, Nurhikmah \\ Sport and Education Study Program, University of Muhammdiyah Luwuk Banggai, Banggai, 94711, Sulawesi Tengah, Indonesia
}

Received September 22, 2020; Revised December 11, 2020; Accepted December 20, 2020

\section{Cite This Paper in the following Citation Styles}

(a): [1] Muhammad Salahuddin, Armin Haluti, Nurhikmah , "Futsal Sports Coaching Achievements of Banggai Regency (A Case Study in Banggai Regency)," International Journal of Human Movement and Sports Sciences, Vol. 9, No. 1, pp. 117-123, 2021. DOI: 10.13189/saj.2021.090116.

(b): Muhammad Salahuddin, Armin Haluti, Nurhikmah (2021). Futsal Sports Coaching Achievements of Banggai Regency (A Case Study in Banggai Regency). International Journal of Human Movement and Sports Sciences, 9(1), 117-123. DOI: 10.13189/saj.2021.090116.

Copyright $\subseteq 2021$ by authors, all rights reserved. Authors agree that this article remains permanently open access under the terms of the Creative Commons Attribution License 4.0 International License

\begin{abstract}
Banggai regency futsal sport is quite well known among the people, but no futsal athletes have been able to compete at the provincial or national level such as in the provincial sports championship (Porprov) held in Moutong in 2019. Even though seeing many futsal athletes who have talent, skill, and good ability in playing futsal when participating in the championships that held in the district, this futsal development especially the futsal district association (AFKAB) has not shown achievements. The purpose of this research is to find out: the quality of athletes, coaches, training programs, organizations, facilities and infrastructure, funding for the Banggai Regency Futsal Association. This research was conducted in Banggai Regency, Central Sulawesi. The method used in this research is a qualitative method using questionnaire or questionnaire. The results of this research in the classification of the quality of futsal athletes in Banggai Regency the frequency of futsal athletes in Banggai Regency are classified as Good with criteria of 17 people or $51.5 \%$ of 33 athletes. The quality of the trainers is quite poor with a frequency of 2 people or $66.7 \%$ of the 3 trainers. The quality of the training program is quite poor with a frequency of 2 people or $66.7 \%$. The quality of the organization is good with a frequency of 3 people or $60 \%$ of 5 management. The quality of facilities and infrastructure is classified as poor in terms of athletes, trainers and administrators. The quality of funding is classified as good with a frequency of 3 people or $60 \%$ of 5 management. The quality of athletes in fostering Futsal sporting achievements in Banggai Regency is included in
\end{abstract}

good criteria, seen from the spirit of training and athletes' efforts in achieving optimal performance. The conclusion of this study: the quality of athletes, administrators and funding is good while the quality of trainers, training programs, facilities and infrastructure is still not good in fostering futsal achievement in Banggai Regency. So the development of futsal sporting in Banggai Regency needs to get special attention for the trainers, facilities and infrastructure of the KONI management and the Government.

Keywords Coaching, Achievement, Sport, Futsal

\section{Introduction}

The Regency Futsal Association (AFKAB) of Banggai is an organization under the auspices of the PSSI and has only been formed by the board since 2016 to date, but increasing achievements at the regional, provincial, national and international levels have yet to produce results. In fact, Banggai Regency, as one of the districts that has the potential to develop futsal, sees athletes who have potential above the average of every championship event made in the district.

Sport is a form of physical activity carried out in accordance with the program and measured by involving members of the body to form personality, discipline and spirit of sportsmanship to improve physical fitness. Futsal 
sports in Banggai Regency can be said to be very rapidly developing. Sports achievements are achieved through various efforts in all its aspects. Banggai Regency futsal is quite well known in the community, but no futsal athletes have been able to compete at the provincial or national level as in the provincial sports championship (Porprov) held in Moutong in 2019. Even though seeing futsal athletes when participating in the championships held in the district, many athletes have very good talents, skills, and playing abilities, but this fusal development especially the futsal district association (AFKAB) has not shown achievements between regions, provinces and even international achievements. Seeing the lack of attention and coaching in improving achievement, so that futsal athletes are only able to play with individual abilities and lack of support from the government, athletes can play futsal with the initiative of futsal fans who always participate every time a match made in Banggai Regency. Even though Banggai Regency can be said that the athlete's potential can be formed with the existence of good coaching, it is proven that the athlete follows the local championship. So with this, it is necessary to study the extent of the steps for the development and fostering of futsal district sports achievements. Banggai regency sports achievements began difficult to improve the development of his achievement, because it began to approach the point of saturation.

Achievement is a result of what has been achieved or a result of something achieved before (Kurniawan, 2020) [1]. Whereas Sports Achievement is a sports activity carried out by coaching and developing athletes in a structured, tiered and sustainable manner to achieve an achievement with the support of sports science and technology. Thus the futsal achievement of Banggai Regency can be developed by creating a structured and transparent program so that the training of these athletes can make a good contribution for improving the progress of achievement in the field of sports.

Nugroho (2017:164) [2] like have been cited from republic of Indonesia number 3 of 2005, regarding the development and development of sports in Chapter VII general section one of article 21 paragraph (1) the government and regional governments are required to conduct sports development and guidance in accordance with their authority and responsibilities. Paragraph (2) development and development as referred to in paragraph (1) cover sports, personnel, organization, funding, methods, infrastructure and facilities, as well as sports awards as well as talent development and performance improvement.

The problem in this study is that the Futsal Association of Banggai Regency has not been able to compete with outside regions in Central Sulawesi province even though the potential of the existing athletes is quite good in the game of futsal, so that in several matches made in Central Sulawesi, Banggai Regency Futsal has never given such achievements scintillating for the area. Seeing these conditions, the researchers tried to explore the problems experienced by AFKAB Banggai, so that in the future, they could be better and ahead in the sport of playing futsal.

Futsal is a game played on a synthetic field with the aim of scoring goals against your opponent to win the game.Futsal sport is a game that is played on a synthetic field with the aim of scoring goals to your opponent to get a win. Futsal is a team game that ignores how many goals are scored, but plays creates goals to lift achievements (Justinus Lhaksana, 2011: 7-8) [3]. Fostering achievement both regional and national must become a system that can be controlled so that young people can monitor the talent of athletes in the region so that fostering achievement can develop properly. Coaching is a major factor in sports which is very important in achieving increased sports achievement, (Nugroho, 2017: 162) [2].In fact, it is coaches' behavior that potentially impacts on what coming after the sport practices (Hagan Jnr, et.al,2017) [4].Sports coaching starts from an early age to reach adulthood and reaches a level of success (Nugroho, 2017: 165) [2]. Optimal achievements can be achieved and must be supported by various stages of sports coaching. States that the process of increasing athlete achievement coaching, talented athletes will not be able to achieve without serious coaching, including: assassination, nursing, talent scouting, trainers, training program, facilities and infrastructure, organization, and funding.

The main problem related to these components is related to the absence of standard requirements for professional sports coaches that are built systemically, (Nugroho,2017:163) [2]. Supposialization is modeling the skills and physical fitness in multilateral and specialization. Athlete breeding is looking for talented athletes in accordance with the sport in which they are interested, and then provides coaching on a scheduled basis and an innovative system so that it can produce athletes who excel in. Talent scouting is a coaching that is carried out starting from predicting the athlete's own talent by providing a structured training program so as to get an athlete's success. According to Rohman (2017: 101) [5], the competence of a trainer is someone whose capabilities to transfer knowledge to athletes and to show the techniques to the athletes so they can make movements properly and correctly. Provide knowledge and experience that has been obtained. Trains who have high capability, sportsmanship, honest and full of responsibility, then in fostering experts will be done with all his heart for the success of an athlete. The training program is a program that is carried out to be fun for athletes, effective, efficient and able to measure the goals achieved (Susanto \& Lismadiana, 2016: 100) [6]. In training, both athletes and trainers must not be separated from a program, because the program is part of a benchmark for the success rate of training given to athletes. Organizations are associations 
of people or groups that have been formed and have the duties and responsibilities that have been given that there are institutions involved in it to achieve common goals and objectives. However, business management of organization with vertical structures has some issues in departments and unnecessary competition (Samur, 2018) [7].It should not be like this since the organization has to coordinate everything so that the process of carrying out activities runs smoothly and mutual expectations are realized (Wicaksono, 2015: 1911) [8].With the existence of an organization, it can be used as a forum for the development and fostering of more efficient achievements, because the organization already has a program for improving achievement.

Facilities and infrastructure is a supporting and determining factor for organizing an event and other activities. Sports facilities and infrastructure are used to support both mobile and immovable sports activities that can be used as activity organizers directly or indirectly (Firdausdkk., 2015: 87) [9]. Funds are everything that must support every activity carried out. Funds are the most urgent issue in the activities to be carried out. Without funds to support athletes' achievements, all will be in vain, because athletes need funds to increase their intake of gears both in training and in matches.

The research objectives in improving Futsal performance in Banggai Regency are to determine: 1) the quality of AFKAB athletes, 2) the quality of AFKAB trainers, 3) the quality of the AFKAB training program, 4) the quality of AFKAB organization, 5 the quality of AFKAB facilities and infrastructure, and 6) the quality of AFKAB funding in Banggai Regency.

\section{Materials and Method}

\subsection{Time and Place of the Research}

This research was conducted from April - July 2020 in Banggai Regency.

\subsection{Types and Research Variables}

The type of research used in this study is to use qualitative methods on the grounds that qualitative research is able to provide a complete and in-depth picture of fostering soccer sports achievement (Nugroho, 2017: 165) [2].

The research variables used are independent and dependent variables as follows:

1. Independent variables are athletes, coaches, training program, organisation, facilities, and funding.

2. Dependent variable is the futsal achievement development the Development of Banggai Regency Futsal Achievement.

\subsection{Population and Sample}

Population is a conclusion that can be used as an object or sample that has been tested for its existence which has a predetermined quality, (Sugiyono, 2012: 61) [10]. The sample is a portion of the population used as the sample. The sample in this study included 33 athletes, 3 coaches, five active Banggai District futsal administrators. So the number of samples was 41 people. If the population is less than 100 people, it will be the whole sample, Suharsimi Arikunto (2012: 130) [11] The total sample used was 41 people.

\subsection{Data Collection Technique}

According to Nurlia (2020: 99) [12], the sampling technique is proportional random sampling. The number of samples was determined by calculating the total sample size using the Taro Yamne formula. The data collection instrument used was a questionnaire with a research sample of 41 people, and the rest was additional data such as documents and others. The documentation method is used to extract data from written sources, photos and statistical data. The distribution of questionnaires was carried out face-to-face and was limited to the number of samples used due to the covid pandemic conditions 19 . The questionnaire was divided into several sections. The athlete had 21 questions, the coach had 29 questions and the administrators had 21 questions. The distribution of the questionnaire was carried out in stages.

\subsection{Research Data Analysis}

\subsubsection{The Frequency of Athletes' Quality}

The athlete's quality frequency, the results obtained from 33 athletes included unfavorable criteria of 4 people or $12.1 \%$, unfavorable criteria of 10 people or $30.3 \%$, good criteria of 17 people or $51.5 \%$, while those who said athlete's quality criteria is very good are 2 people or $6.1 \%$. So the frequency distribution of Banggai Regency futsal athletes is classified as Good with a criterion of 17 people or $51.5 \%$.

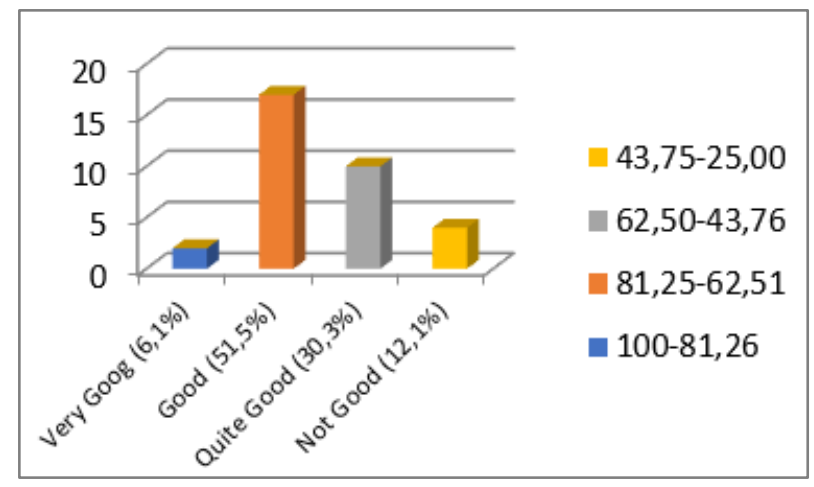

Figure 1. Athletes’ Quality 


\subsubsection{The Frequency of Trainers' Quality}

The frequency of trainers who said it was not good was 0 people; the frequency of trainers who said it was not good was 2 people or $66.7 \%$. The number of trainers who said either was 1 person or $33.3 \%$. The frequency of athletes who say very well is 0 people. So the quality of futsal trainers in Banggai Regency is generally poor with a frequency of 2 people or $66.7 \%$.

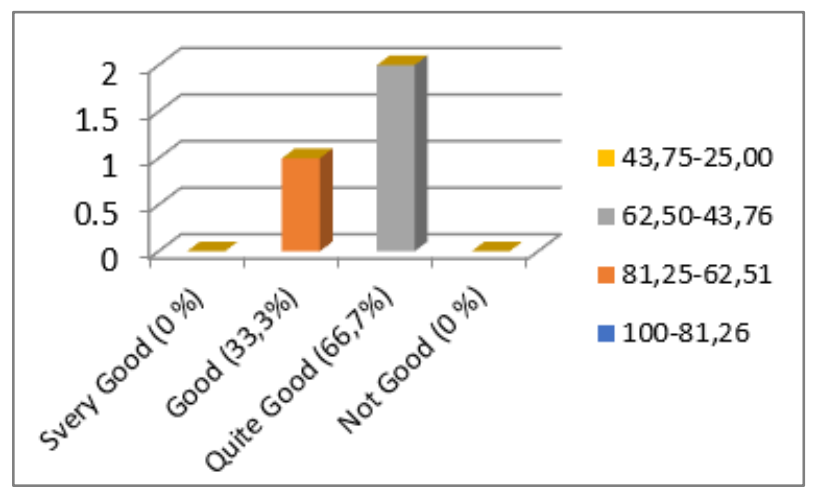

Figure 2. Trainers’ Quality

\subsubsection{The Frequency of Training Program’s Quality}

The frequency of trainers who said it was not good was 0 people; the frequency of trainers who said it was not good was 2 people or $66.7 \%$. The number of trainers who said either was 1 person or $33.3 \%$. The frequency of athletes who say very well is 0 people. So the quality of the Banggai Regency futsal athlete training program on average is not good with a frequency of 2 people or $66.7 \%$.

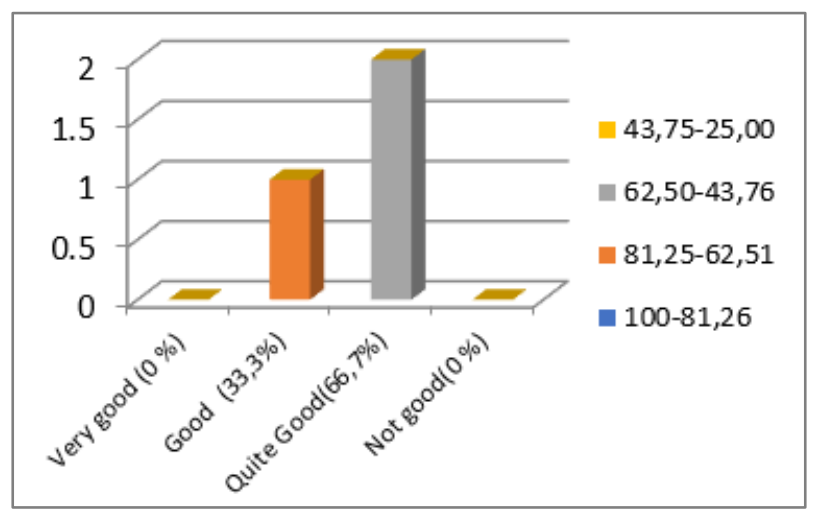

Figure 3. Training Program’s Quality

\subsubsection{The Frequency of Organization}

The frequency of organizations that said it was not good was 0 people; the frequency of organizations that said it was not good was 2 people or $40 \%$. The frequency of organizations that say either is as many as 3 people or $60 \%$. The frequency of organizations that say very well is as many as 0 people. So the frequency of the AFKAB futsal Banggai Regency management organization on average is good with a frequency of 3 people or $60 \%$.

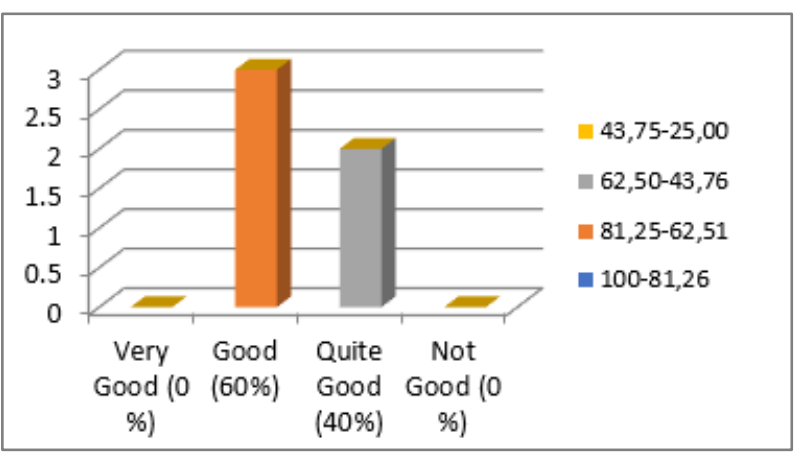

Figure 4. Organization

\subsubsection{The Frequency of Facilities and Infrastructure}

The results obtained from 33 athletes whose frequency of facilities and infrastructure that said it was not good were 2 people $6.1 \%$; the frequency of facilities and infrastructure said it was not as good as 20 people or $60.6 \%$. The frequency of facilities and infrastructure that said either is as many as 10 people or $30.3 \%$. The frequency of facilities and infrastructure that says very well is as many as 1 person or $3.0 \%$. So, the frequency of AFKAB futsal facilities in Banggai Regency on average is not good with a frequency of 20 people or $60.6 \%$.

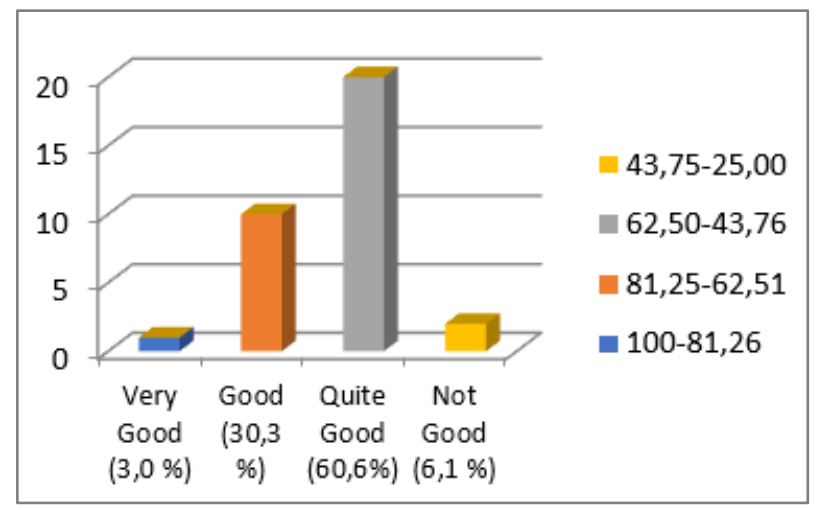

Figure 5. Facilities and Infrastructure

\subsubsection{The Frequency of Funding}

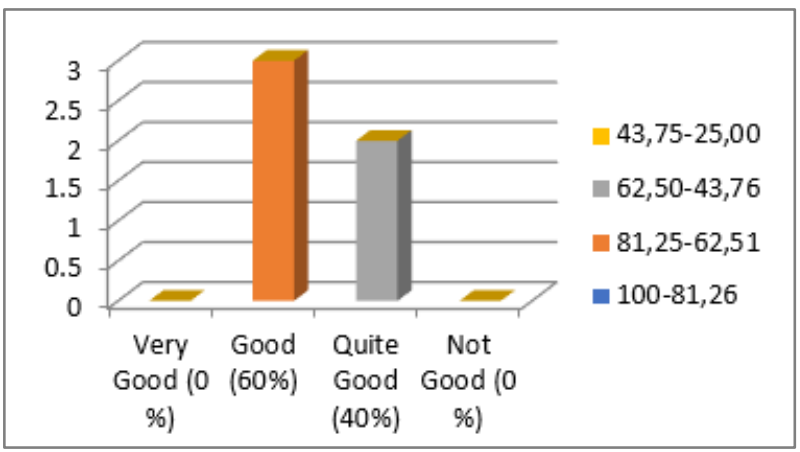

Figure 6. Funding

The frequency of funding which said not good is as many as 0 people; the frequency of facilities and infrastructure said it was not as good as 2 people or $40 \%$. The frequency of facilities and infrastructure that says 
either is 3 people or $60 \%$. The frequency of facilities and infrastructure that said very good is as many as 0 people. So the frequency of funding in terms of the management of Banggai Regency AFKAB futsal on average is good with a frequency of 3 people or $60 \%$.

\subsection{Discussion of Research Results}

Table 1. Research Results data Recapitulation

\begin{tabular}{|c|c|c|c|c|c|}
\hline \multirow{2}{*}{ Variable } & \multicolumn{4}{|c|}{ Criteria } & \multirow{2}{*}{ Notes } \\
\hline & SB & B & KB & TB & \\
\hline Athlete Quality & 2 & 17 & 10 & 4 & Good \\
\hline Coach Quality & 0 & 1 & 2 & 0 & Not Good \\
\hline $\begin{array}{c}\text { Quality of the } \\
\text { Exercise Program }\end{array}$ & 0 & 1 & 2 & 0 & Not Good \\
\hline Organisation & 0 & 3 & 2 & 0 & Good \\
\hline $\begin{array}{l}\text { Facilities and } \\
\text { Infrastructure } \\
\text { according to } \\
\text { Athletes }\end{array}$ & 1 & 10 & 20 & 2 & Not Good \\
\hline $\begin{array}{l}\text { Facilities and } \\
\text { Infrastructure } \\
\text { according to } \\
\text { Coaches } \\
\end{array}$ & 1 & 0 & 2 & 0 & Not Good \\
\hline $\begin{array}{l}\text { Facilities and } \\
\text { Infrastructure } \\
\text { according to the } \\
\text { Administrators }\end{array}$ & 0 & 1 & 3 & 1 & Not Good \\
\hline Funding & 0 & 3 & 2 & 0 & Good \\
\hline
\end{tabular}

\subsubsection{Athlete Quality}

The results of data analysis that have been carried out in the classification recapitulation show that the quality frequency of Banggai District futsal athletes is in good criteria, because of the 33 athletes studied, 2 were categorized as very good, 17 were categorized as good, 10 were categorized as not good, and 4 were categorized as bad. An athlete will be able to provide achievements if supported by coaching, existing facilities, transparent funding, effort, and a spirit of practice. The spirit of training and the efforts of athletes in achieving an achievement are included in the Good category. So the quality of athletes to improve futsal performance in Banggai Regency is classified as good or significant

\subsubsection{Coach Quality}

Trainers are the backbone and role models for athletes in the sports they coach (Suwirman, 2019: 3) [13]. A trainer is someone who is able to foster and provide the knowledge and experience that has been obtained (Rohman, 2017: 93) [5]. The results of the recapitulation data analysis show that the Banggai District futsal coach has been certified coach. Based on the results of descriptive analysis in the recapitulation of research data on the quality variable of Futsal coaches in Banggai Regency, it is in the poor category, because from the 3 coaches studied, 1 coach stated good and 2 coaches stated not good. From the coaches certified data, there are still 2 coaches who are lacking in knowledge and guidance. So there must be an increase in training development. So the quality of coaches to improve futsal performance in Banggai Regency is classified as poor or significantly less.

\subsubsection{Quality of the Exercise Program}

The results of the descriptive analysis in the research data recapitulation of the exercise program variables show that from 3 coaches, 2 of them were categorized as not good and 1 was categorized as good. This can be seen from the training program provided in Futsal development in Banggai District which is categorized as unfavorable. Not only the training program planning is still in the not good category, but the evaluation of the training program implementation is still in the not good category too. So the quality of the training program to improve futsal performance in Banggai Regency is classified as poor or significantly less

\subsubsection{Organization Quality}

Organization is important for coordinating everything so that the process of carrying out activities runs smoothly and the realization of common hopes (Wicaksono, 2015: 1911) [8]. Descriptive data analysis in the recapitulation of the research data shows that the 5 administrators included in the Futsal management organization variable in Banggai District are categorized in good criteria, with the classification, saying good was 3 people and those who say not good were 2 people. This can be viewed in terms of management where the board pays attention to the origin and management of the Futsal management in Banggai Regency. So the quality of the organization towards improving the futsal performance in Banggai Regency is good or significant

\subsubsection{Facilities and Infrastructure Quality}

Based on the results of descriptive analysis in the data recapitulation of the research results on the variables of facilities and infrastructure owned by Banggai District, athletes say that the facilities and infrastructure owned are still in the criteria not good, because out of 33 athletes, only 1 athlete said they were very good, 10 athletes said they were good, no one said they were not good, and 2 athletes said they were bad. According to the coaches, the facilities and infrastructure owned by Banggai District are in not good criteria because out of 3 coaches, 1 coach said it was very good, and 2 coaches said it was not good. This can be seen from the completeness and quality, as well as the procurement model for the facilities and infrastructure itself. According to the management, the facilities and infrastructure owned by Banggai District were included in the not good criteria, because out of 5 administrators, 1 administrator said it was not good, 3 administrators said it was good, 1 administrator said it was not good. This can be seen from the completeness and quality of the facilities 
and infrastructure in terms of the procurement model of the facilities and infrastructure. So the quality of facilities and infrastructure for improving futsal performance in Banggai Regency is classified as poor or insignificant

\subsubsection{Funding Quality}

According to Muslimin (2017: 60)[14], funds are one of the factors that support the results of coaching because without funds, coaching will be difficult to progress towards maximum achievement. The results of descriptive analysis in the recapitulation of research data on funding variables owned by AFKAB Banggai Regency indicate that the implementation of futsal sports performance coaching is included in good criteria, because of the 5 administrators, 3 of them said good and 2 administrators said they were not good. This can be seen from the source of funding and how to allocate funds for the coaching process.So the quality of funding for improving futsal performance in Banggai Regency is good or significant

\subsection{Research Findings}

The findings from research on the achievements of Futsal in Banggai District include:

1. For athletes, looking at the findings obtained in improving performance for athletes, especially in Banggai District, that the willingness and effort of athletes are in accordance with existing abilities in good criteria. However, they still lack of support or are not too serious in terms of the coaching carried out by the management and local government.

2. For coaches, having an increase in the quality of certification and training programs is important in order to improve the quality of its legality. So that the coaching carried out is not just based on experience.

3. In an effort to improve futsal performance in Banggai District, if we want to get athletes who excel, we must be in line between athletes, coaches, and administrators so that an athlete development can run well. However, in this study, the three elements were still not in line with each other.

\section{Conclusions}

1. The quality of athletes in fostering Futsal sporting achievements in Banggai Regency is included in good criteria, seen from the spirit of training and athletes' efforts in achieving optimal performance.

2. The quality of Futsal trainers in Banggai Regency is not good, because only some of the trainers have trainer certification, and their knowledge in fostering Futsal guidance is still lacking.

3. Training programs provided in the development of Futsal sports in Banggai Regency are included in the unfavorable criteria. Judging from the planning of the training program that is still lacking, as well as the evaluation of the implementation of the training program is also still lacking.

4. The organization of Futsal management in Banggai Regency is included in the criteria both seen from the attention of the management to the athlete, and the management of Futsal Banggai Regency itself.

5. Facilities and infrastructure owned by Banggai Regency according to athletes are included in the criteria both in terms of the completeness and quality of existing facilities and infrastructure. According to the trainers, the facilities and infrastructure owned by Banggai Regency are included in the criteria that are not good from the completeness and quality, as well as the model of the procurement of facilities and infrastructure itself, while according to the management of facilities and infrastructure owned by Banggai Regency are included in the criteria both in terms of both the completeness and quality of the facilities and the infrastructure is good, the model of procurement of facilities and infrastructure.

6. Funding owned by AFKAB Banggai Regency for the implementation of Futsal sports achievement coaching is included in the criteria both in terms of funding sources and how to allocate funds for the coaching process.

\section{Acknowledgments}

- Thanks to Mr. Rector, who has given permission to participate in the implementation of this study

- Thank you also the Dean of the Teaching and Education Faculty of Muhammadiyah University of Luwuk for the time permission that has been given Thank you to the Head of LP3M University of Muhammadiyah Luwuk for your cooperation in this research so that they can carry out this research.

- Thank you to all the committee for their cooperation so that research can be carried out.

- Thank you to all athletes, trainers and administrators of Banggai district Futsal for the time and opportunity for their permission so that this research can run smoothly. Panitia atas bantuan kerjasamanya sehingga penelitian bisa terlaksana.

\section{REFERENCES}

[1] Kurniawan A. Definition of Achievement - Kinds, Meanings, Attitudes, Factors, Giving, Methods, Experts Online tersedia dari Diposting pada 23/03/2020 https://www.gurupendidika n.co.id/pengertian-prestasi/

[2] Nugroho, Wahyu A. Development of Football Sports Achievement at the Putra Batang Education and Training 
Center, Juara: Jurnal Olahraga, Vol.2, No.2, 161-173..

[3] Lhaksana, Justinus. Modern Futsal Tactics \& Strategy. Jakarta: Penebar Swadaya Group. 2011

[4] Hagan Jnr, John Elvis; Ansah, Edward Wilson; Pollmann, Dietmar; \&Schack, Thomas. 2017. Elite Student-Athletes' Perceptions of Coaches' Behavior during the 23rd World Universiade Games in Kazan, Russia. International Journal of Human Movement and Sports Sciences 5(4): 68-76, 2017.

[5] U. Rohman.2017. Improving the Quality of PencakSilat Coaches in Dharmasraya District Evaluation of the Competence of Early Age Football Coaches in Football Schools, Jurnal Pendidikan Jasmani dan Olahraga. Vol. 2, No.2, 92-104.

[6] Susanto, Nugroho \& Lismadiana. 2016. Management of the Yogyakarta Gama Football Training Program (SSB), Jurnal Keolahragaan, Vol.4, No.1, 98-110.

[7] Samur, Serdar. 2018. Organization Design in Football Management Process. International Journal of Human Movement and Sports Sciences 6(2): 38-46, 2018.

[8] Wicaksono, B.A. 2015. Development of Football Achievement in Football School (ssb) TuguMuda Semarang
City 2012/2013, Journal of Physical Education, Sport, Health and Recreations, Vol.4, No.7. 1911-1914.

[9] Firdaus, M; Mardiyanto, A; \& Purnomo, I. 2015 Utilization of Selomanggeng Recreational Park (Klotok) as Sports Facilities and Infrastructure for the Community of Kediri City, Juornal Sportif , Vol. 1, No.1, 81-99.

[10] Sugiyono. Understanding Qualitative Research, ALFABETA, Bandung, 2012.

[11] Arikunto, Suharsimi. Research Procedure A Practice Approach. rev.ed. Jakarta : PT. RinekaCipta. 2012.

[12] Nurlia. The Relationship between Naturalistic Intelligence and Learning Interest with Biology Learning Outcomes of High School Students in Luwuk City. Luwuk, Jurnal Pendidikan Glasser, Vol.4 No 2, 97-106.

[13] Suwirman. Improving the Quality of Pencak Silat Trainers in Dharmasraya District, Jurnal berkarya pengabdian masyarakat Vol.1 No.1.2019

[14] Muslimin, A. Hidayat. Evaluation of the 2016 South Sumatra Sriwijaya State Sports School Football Team Development Program. Journal Sport Area, Vol.2, No 2, 53-62. 